\title{
REMOVAL OF SELENATE AND COBALT BY GOETHITE AND NANO PARTICLES ZERO-VALEANT IRON FROM AQUATIC SYSTEMS.
}

Sherif, A. E. A.; S. A. El-Tohamy and Wafaa A.Hafez

Soil, Water and Environment Res. Inst., Agric. Res. Center, Giza, Egypt.

\begin{abstract}
The objective of this study is to investigate the effect of $\mathrm{pH}$ variation from 3 to 12 on adsorption of Se and Co on synthetic goethite and nano particles zero-valeant iron. Therefore, series of well-controlled laboratory experiments were carried out on the previous materials.

Maximum adsorption on goethite and nano particles zero-valeant iron (nZVI) for selenate occurred at the initial concentration of $10 \mu \mathrm{g} \mathrm{Se} \mathrm{mL}{ }^{-1}$ where nearly $99.8 \%$ and $100 \%$ of the total applied selenate was adsorbed at a $\mathrm{pH}$ range of $3-4$ for goethite and $\mathrm{pH} 3$ for (nZVI). With increasing $\mathrm{pH}$ to more than 4 , selenate adsorption tended to decline sharply to be $3.3 \%$ and $3.5 \%$ of the total Se added at $\mathrm{pH} 11$ for goethite.

Selenate adsorption decreased almost linearly from almost $3119.7 \mu \mathrm{g} \mathrm{g}^{-1}$ goethite at $\mathrm{pH} 3.0$ to $104.4 \mu \mathrm{g} \mathrm{g}^{-1}$ goethite at $\mathrm{pH} 11$ and corresponding to $24855 \mathrm{\mu g} \mathrm{g}^{-1}$ (nZVI) at $\mathrm{pH} 4.0$ to $4160 \mathrm{\mu g} \mathrm{g}^{-1} \mathrm{nZVI}$ at $\mathrm{pH} 11$.

The lower adsorption of selenate at high $\mathrm{pH}$ values is probably attributed to an increase in repulsion between the more negatively selenate species and negatively charged surface sites. Adsorption of Co showed an opposite behavior to selenate as its adsorbed quantities increased with increasing $\mathrm{pH}$. The highest Co adsorption was noticed at $\mathrm{pH} 8.0$ with a constant adsorption values with $\mathrm{pH}>9.0$. The highest $\mathrm{Co}$ adsorption was $2771 \mathrm{\mu g} \mathrm{g}^{-1}$ goethite and $20240 \mathrm{\mu g} \mathrm{g}^{-1}$ (nZVI), which corresponded to $89 \%$ and $81 \%$ of total added Co for goethite and (nZVI), respectively.

Keywords: Removal - Selenate - Cobalt - Goethite -Nano particles Zero-Valeant Iron - $\mathrm{pH}-$ Adsorption.
\end{abstract}

\section{INTRODUCTION}

Selenate and cobalt are known to be human carcinogenic elements. Knowledge of reaction kinetics at the solid liquid interface is extremely important in understanding the adsorption /desorption processes controlling solubility of selenate and cobalt in soil and water systems.

Contamination of soil with heavy metals possess serious risks for biota and human health.Cobalt and other heavy metals reach the soil from the air, phosphatic fertilizers and by the incorporation of sewage sludge. Adsorption and desorption strongly affect the bioavailability of heavy metals and therefore toxicity in soil (Renella et al., 2004).

Selenium is present in the environment in both inorganic and organic forms, and in the solid, liquid, and gas phases. Although it can exist in six oxidation states, yet the $\mathrm{II}^{+}$state is not known to exist in nature (Lenz 2008). Heavy metal contamination exists in the aqueous waste streams of many industries, such as metal plating facilities, mining operations, nuclear power plant and tanneries. The soils surrounding many military bases are also contaminated and possess a risk of ground water and surface water 
contamination due to the heavy metals. Some metals associated with these activities are cadmium, chromium, cobalt, lead and mercury. Heavy metals are not biodegradable and tend to accumulate in living organisms, causing various diseases and disorders (Susan et al., 1999, Netzer and Hughes1984and Gomez-Lahoz et al., 1993).

Inorganic forms include $\mathrm{SeO}_{3}{ }^{2-}, \mathrm{SeO}_{4}{ }^{2-}, \mathrm{Se}^{0}, \mathrm{H}_{2} \mathrm{Se}$, and metal selenides (MeSe). Organic forms include alkyl selenides such as dimethylselenide (DMSe) and dimethyldiselenide (DMDSe), selenoaminoacids, and seleno-proteins including selenocysteine and selenomethionine. Selenocystein and selenomethionine are analogues of the sulfur-containing proteins methionine and cystein. Both DMSe and DMDSe are volatile, sparingly soluble, and relatively non-toxic, although both are bioavailable (Shrestha et al., 2006).

Oxidized inorganic forms of selenium exist as highly soluble oxyanions in aqueous systems. Neither $\mathrm{Se}(\mathrm{VI})$ (selenate) nor $\mathrm{Se}(\mathrm{IV})$ (selenite) anions react with common cations such as calcium or magnesium, therefore they tend to remain in solution. Se(IV) species are more reactive than $\mathrm{Se}(\mathrm{VI})$ species and are easier to reduce to elemental selenium (Chapman, 2000). Nevertheless, elemental colloidal selenium particles are easily transported through aqueous systems (Haygarth, 1994).

Selenium speciation and therefore remediation is highly dependent on $\mathrm{pH}$ and redox potential (Eh). Selenate and selenite are often found outside their predicted thermodynamically stable zones (Microbial Technologies, 2005).

Nano particles zero-valent iron ( $\mathrm{nZVI})$ is used to reduce selenium oxyanions to elemental selenium. Ferrous cations can also reduce selenate to selenite and subsequently remove selenite by adsorption to iron hydroxides. In an aqueous environment, ZVI can be oxidized to ferric $\left(\mathrm{Fe}^{3+}\right)$ and ferrous $\left(\mathrm{Fe}^{2+}\right)$ ions. These ions react with hydroxyl ions present in water to form ferric and ferrous hydroxides. Selenate is reduced to selenite while ferrous iron is oxidized to ferric iron. Selenite is then adsorbed on the ferric and ferrous hydroxide surfaces and is removed from solution. Iron reduction removal mechanisms are as follows:

$$
\begin{aligned}
& \mathrm{SeO}_{4}{ }^{2-}+\mathrm{ZVI} \rightarrow \mathrm{Se}^{\circ}+\mathrm{Fe}^{2+} / \mathrm{Fe}^{3+} \\
& \mathrm{SeO}_{3}{ }^{2-}+\mathrm{ZVI} \rightarrow \mathrm{Se}^{\circ}+\mathrm{Fe}^{2+} / \mathrm{Fe}^{3+} \\
& \mathrm{SeO}_{4}{ }^{2-}+2 \mathrm{Fe}(\mathrm{OH})_{2}+\mathrm{H}_{2} \mathrm{O} \rightarrow \mathrm{SeO}_{3}{ }^{2-}+2 \mathrm{Fe}(\mathrm{OH})_{3}
\end{aligned}
$$

Available data suggest that the best $\mathrm{pH}$ for selenite adsorption ranges between 4 and 6 , producing $85-95 \%$ removal of selenite, on the other hand, pHs greater than 7 show drastic decreases in adsorption. Selenate adsorption may be strongly affected by the presence of sulphate, bicarbonate, and aqueous silica species (Lovett 2008). The measured mobility of Co also depends on $\mathrm{pH}$, and the ionic strength of the extracting (Naidu et al,1994).

Selenium also accumulates in soils through the use of fertilizers and irrigation water containing Se (Bisbjerg, 1972). In fertilizers, ammonium sulphate contains up to $36 \mathrm{mg} \mathrm{kg}-1$, phosphate rocks up to $55 \mathrm{mg} \mathrm{kg}^{-1}$, and single superphosphate up to $25 \mathrm{mg} \mathrm{kg}^{-1}$ Se (Swaine, 1962 and Bisbjerg, 1972).However, since single superphosphate has generally been replaced by 
triple superphosphate, which contains up to $4 \mathrm{mg} \mathrm{kg}^{-1} \mathrm{Se}$, fertilizer inputs of Se to soils have fallen.

Cobalt, a natural element present in certain ores of the Earth's crust, is essential to life in trace amounts. It exists in the form of various salts. Pure cobalt is an odorless, steely-gray, shiny, hard metal. Everyone is exposed to low levels of cobalt in air, water and food. An average of $2 \mathrm{gdm}^{-3}$ in drinking water has been estimated. Cobalt has both beneficial and harmful effects on health. Important natural sources of cobalt in the environment are soil, dust and sea water. Cobalt and its salts are used in nuclear medicine, enamels and semiconductors, grinding wheels, painting on glass and porcelain, hygrometers and electroplating; as a foam stabilizer in beer, in vitamin B12 manufacture, as a drier for lacquers, varnishes and paints, and as a catalyst for organic chemical reactions. The permissible limits of cobalt in the irrigation water and livestock watering are 0.05 and $1.0 \mathrm{mgdm}^{-3}$, respectively (Environmental Bureau of Investigation, Canadian Water Quality Guidelines).

A number of technologies have been developed over the years to remove toxic cobalt from water, including chemical precipitation, electro flotation, ion exchange, reverse osmosis and adsorption on activated carbon (Poon, 1986).

The removal of heavy metal pollutants at high concentrations from water can be readily accomplished by chemical precipitation or electrochemical method. At low concentrations, removal of such pollutants is more effectively implemented by ion exchange or adsorption on solid sorbent such as activated carbon (Sigworth and Smith., 1972).

The IRN77 and SKN1 are effective for removal of Co (II) over the pH range 2-8. For comparison, revealed that precipitation curve at different $\mathrm{pH}$ values in the absence of resins. The precipitation of Co (II) was observed at $\mathrm{pH} 8.5$.

At any $\mathrm{pH}$, the removal of metal cation is much greater by adsorption than by hydroxide precipitation. The adsorption of the metal cation on adsorbent depends on the nature of the adsorbent surface and species distribution of the metal cation. For the IRN77 and SKN1 resins, the adsorption at $\mathrm{pH}$ above 8 shows a decreasing trend because of the formation of hydroxyl complexes of cobalt, $\mathrm{Co}(\mathrm{OH})_{2}$ (Periasamy et al. 1991).

Precipitation may also occur, especially in the high $\mathrm{pH}$ range. Precipitation of hydroxides and carbonates that are formed above $\mathrm{pH} 8$ may be misinterpreted as large distribution coefficients, especially if the batchequilibration method is used. The $\mathrm{pH}$ in this investigation was limited to less than 7 so that no precipitation would occur.

The objective of this study is to investigate the effect of $\mathrm{pH}$ variation on adsorption of $\mathrm{Se}$ and $\mathrm{Co}$ on synthetic goethite and zerovalent iron.

\section{MATERIALS AND METHODS}

This experiment was carried out to evaluate the adsorption of selenate or cobalt under different $\mathrm{pH}$ values by synthetic goethite and zerovalent-iron with a back ground of $0.1 \mathrm{M} \mathrm{NaCl}$. 


\section{Synthesis of goethite:}

Goethite was synthesized through a laboratory experiment according to the procedure of Schwartzman and Cornell (1991). Iron was measured in the last solution using the Atomic Absorption Spectroscopy of Perkin Elmer 3300 . The concentration of goethite in the final suspension was $32 \mathrm{gL}^{-1}$. Small portion of goethite suspension was taken, freeze-dried and the identity of goethite was confirmed by powder X-ray diffraction analysis as presented in Fig. (1).

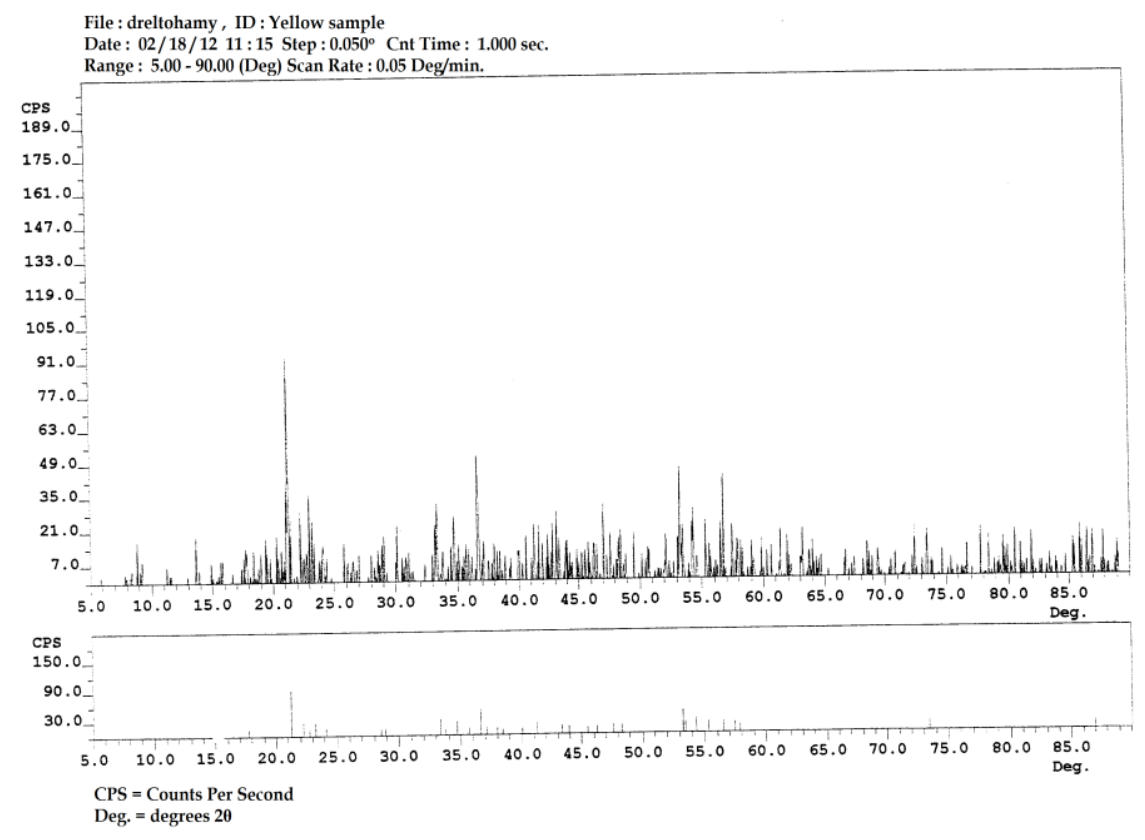

Fig (1): X-ray diffraction analysis of goethite

\section{Selenate and cobalt adsorption envelopes (adsorption versus $\mathrm{pH}$ ): Goethite and Zero-Valent iron}

To study the effect of $\mathrm{pH}$ on selenate and cobalt adsorption on goethite and zero-valent iron (iron metal, fine powder); an experiment was conducted as follows: to a $50-\mathrm{mL}$ reaction vessel $2.5 \mathrm{~mL}$ goethite suspension or $0.01 \mathrm{~g}$ zero-valent iron, $2.5 \mathrm{~mL}$ of electrolyte back ground $(0.1 \mathrm{M} \mathrm{NaCl})$ and $250 \mu \mathrm{L}$ of selenium in the form of selenate or cobalt (stock solution $1000 \mu \mathrm{g}$ $\mathrm{mL}^{-1}$ ) were added and the volume was completed to be $25 \mathrm{~mL}$ with deionized water.

The concentration of Se or Co in the reaction vessels was $10 \mu \mathrm{g} \mathrm{mL}^{-1}$. The $\mathrm{pH}$ in the reaction vessels was adjusted to be between 3 to 12. Then the reaction vessels were shaken for $4 \mathrm{~h}$, centrifuged at $3000 \mathrm{rpm}$ for $30 \mathrm{~min}$, 
filtrated and the $\mathrm{pH}$ in the filtrates was measured. The filtrates were sealed in vials and kept for Se or Co determination. The adsorbed selenate or cobalt on goethite and zero valent iron was calculated as the difference between the initial and equilibrium Se or Co amounts in the solution, and plotted against the $\mathrm{pH}$ values.

\section{RESULTS AND DISCUSSION}

\section{Adsorption envelopes (adsorption versus pH) Goethite: Selenate}

Adsorption of selenate on goethite was studied throughout $\mathrm{pH}$ range of 3-12.Goethite, an iron oxide commonly found in soil surface consists of a layer of $\mathrm{Fe}^{3+}$ ions octahedrally coordinated with $\mathrm{OH}^{-}$ions and $\mathrm{H}_{2} \mathrm{O}$ molecules. Specific adsorption of oxyanions varied with $\mathrm{pH}$. Breaks in slopes of the curves represent anion adsorption over wide range of $\mathrm{pH}$ corresponded with pka values for the acid forms of each anion.

The adsorption envelopes for selenate at initial concentration of 10 $\mu \mathrm{g}$ Se $\mathrm{mL}-1$ indicated adsorption of nearly $100 \%$ of total selenate added throughout the $\mathrm{pH}$ of 3-4 (Table,1). With increasing $\mathrm{pH}$ to more than 4 , selenate adsorption declined sharply to be $3.3 \%$ of the total Se at pH11.

The best $\mathrm{pH}$ for selenite adsorption ranges between 4 and 6 , producing 85 $95 \%$ removal of selenate; pHs greater than 7 show drastic decreases in adsorption (Lovett, 2008).

The adsorption envelopes exhibited broad adsorption maxima for selenate in the $\mathrm{pH}$ range of 3-4 which was followed by a gradual decline with increasing $\mathrm{pH}>4$.

Selenate adsorption decreased almost linearly from almost $3119 \mu \mathrm{g}$ Se $\mathrm{g}^{-1}$ goethite, at $\mathrm{pH} 3$ to $104.4 \mu \mathrm{g} \mathrm{Se} \mathrm{g}{ }^{-1}$ goethite at $\mathrm{pH} 11$. The lower adsorption of selenate at high $\mathrm{pH}$ values is attributable to an increased repulsion between the more negatively selenate species and negatively charged surface sites (Raven et al., 1998). The species which introduces the least negative charge in the outer plane will be preferred. Loading also affects the formation of protonated bidentate species. At low $\mathrm{pH}$ the positive particle charge decreases upon adsorption of negatively charged ions like selenate.

At the highest initial concentration of selenate solution, a distinct adsorption maximum was observed at approximately $\mathrm{pH}$. The adsorption envelopes for selenate obtained in this study were almost similar to those observed by other workers e.g. (Manning et al., 1998, Raven et al., 1998, Sun and Doner, 1998 and Lovett, 2008).

Cobalt

In case of Co adsorption on goethite, results in Table (2) indicate that, adsorption of Co showed an opposite behavior to selenate as its adsorbed quantities increased with increasing $\mathrm{pH}$. The highest Co adsorption was noticed at $\mathrm{pH} 8.0$ with a constant adsorption values with $\mathrm{pH}>7.0$. The adsorption process may be responsible for decreasing Co concentration in the equilibrium solution, particularly at $\mathrm{pH}<7.0$. However, at $\mathrm{pH}$ values $>7.0$ both adsorption and precipitation may be hold the responsibility for 
Sherif, A. E. A. et al.

decreasing Co concentration in equilibrium solution and account for the retention of Co by goethite. These results confirmed the results of AlSewailem et al., (2000) who explained the effect of increasing $\mathrm{pH}$ on cadmium adsorption by two complimentary trends: an increasing proportion of $\mathrm{CdOH}^{+}$ions and a decreasing electrostatic potential of the goethite surface.
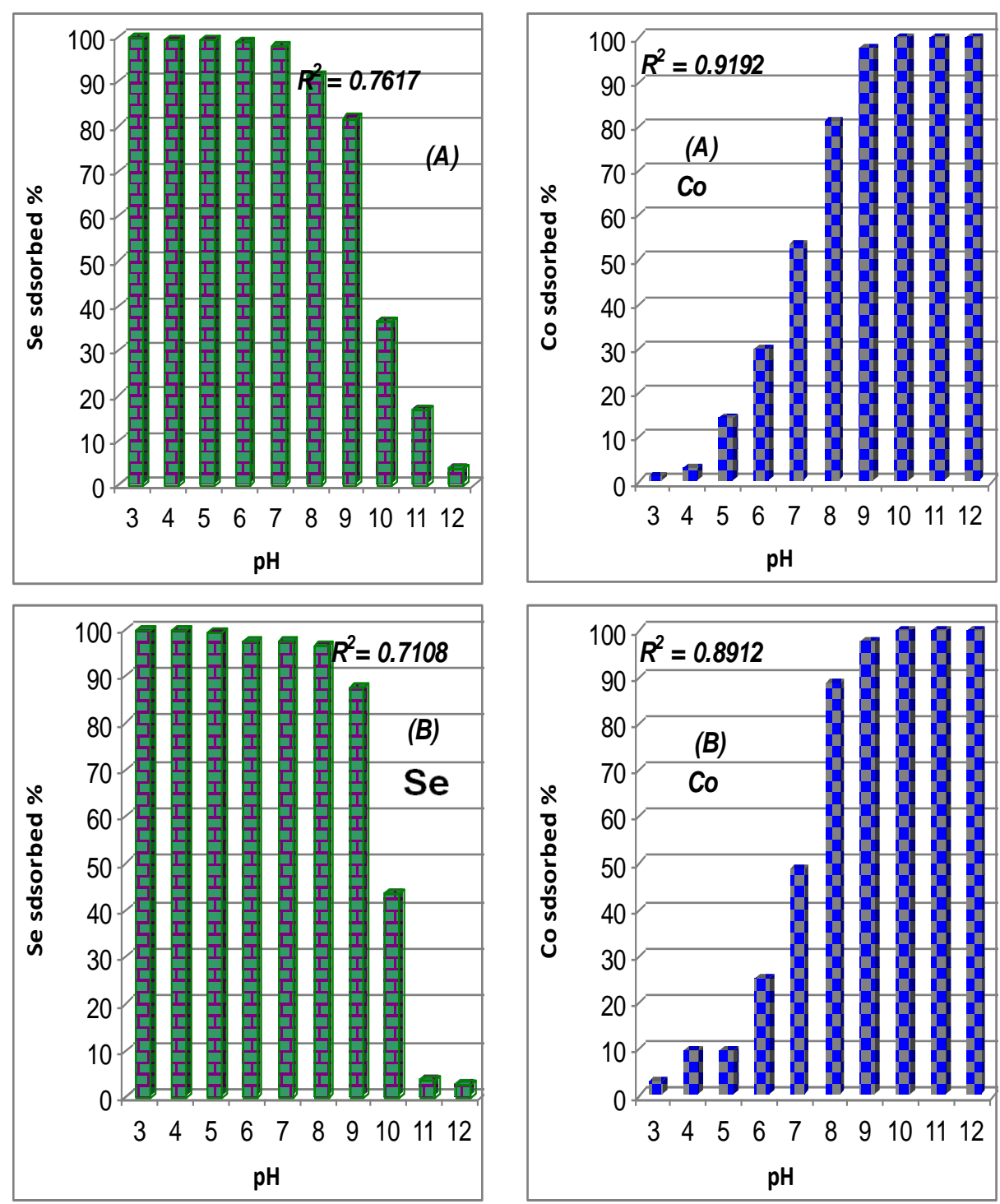

Fig.( 2): Selenate and cobalt adsorption on (A) goethite and (B) $n Z V I$ as a function of $\mathrm{pH}$ (Se and Co $10 \mu \mathrm{g} \mathrm{mL}^{-1}$, ionic strength, $0.1 \mathrm{M}$ $\mathrm{NaCl}$. 
As shown in Fig. (2), the statistical relationship between each of the removed selenium and cobalt by on one hand and the $\mathrm{pH}$ vales on the other one reveal that there were highly significant relations between each of the adsorbed $\mathrm{Se}$ and $\mathrm{Co}$ on of goethite and $\mathrm{nZVI}$ and the $\mathrm{pH}$ values where the values of $(R)$ were 0.84 and 0.94 respectively, in case of goethite while in case of nZVI the corresponding the values of $(R)$ were 0.87 and 0.96 , respectively.

Table (1): Selenate adsorption on goethite as a function of $\mathrm{pH}$ (Se 10 $\mu \mathrm{g}$

\begin{tabular}{|c|c|c|c|c|}
\hline $\begin{array}{l}\text { Initial conc. of } \\
\text { Se } \mu \mathrm{gL} \mathrm{m}^{-1}\end{array}$ & $\begin{array}{c}\mathrm{pH} \\
\text { initial }\end{array}$ & $\begin{array}{c}\mathrm{C} \\
\mu \mathrm{g} \mathrm{mL^{-1 }}\end{array}$ & $\mu g^{q}$ & $\begin{array}{c}\mathrm{pH} \\
\text { Final }\end{array}$ \\
\hline 10.00 & 3.00 & 0.017 & 3119.7 & 3.50 \\
\hline 10.00 & 4.00 & 0.041 & 3112.2 & 3.90 \\
\hline 10.00 & 5.00 & 0.076 & 3101.3 & 3.90 \\
\hline 10.00 & 6.00 & 0.243 & 3049.1 & 4.00 \\
\hline 10.00 & 7.00 & 0.277 & 3038.4 & 3.70 \\
\hline 10.00 & 8.00 & 0.366 & 3011 & 8.70 \\
\hline 10.00 & 9.00 & 1.261 & 2731 & 9.30 \\
\hline 10.00 & 10.0 & 5.663 & 1355.3 & 9.60 \\
\hline 10.00 & 11.0 & 9.666 & 104.4 & 11.0 \\
\hline 10.00 & 12.0 & 9.758 & 75.6 & 11.5 \\
\hline
\end{tabular}

C: Concentration of $\mathrm{Se}$ in equilibrium solution

q:Adsorbed Se

Table (2): Cobalt adsorption on goethite as a function of $\mathrm{pH}$ (Co $10 \mu \mathrm{g}$ $\mathrm{mL}^{-1}$, ionic strength, $0.1 \mathrm{M} \mathrm{NaCl} 32 \mathrm{~g}$ goethite $\left.L^{-1}\right)$.

\begin{tabular}{ccccc}
\hline $\begin{array}{c}\text { Initial conc. of } \\
\text { Co } \boldsymbol{\mu g} \mathbf{~ m L}-\mathbf{1}\end{array}$ & $\begin{array}{c}\mathbf{p H} \\
\text { initial }\end{array}$ & $\begin{array}{c}\mathbf{C} \\
\mathbf{C ~} \mathbf{~ m L}-\mathbf{1}\end{array}$ & $\begin{array}{c}\mathbf{q} \\
\boldsymbol{\mathbf { q }} \mathbf{~ g - 1}\end{array}$ & $\begin{array}{c}\mathbf{p H} \\
\text { Final }\end{array}$ \\
\hline 10.00 & 3.00 & 9.735 & 82.8 & 3.50 \\
10.00 & 4.00 & 9.047 & 297.8 & 3.90 \\
10.00 & 5.00 & 8.090 & 297 & 3.90 \\
10.00 & 6.00 & 7.507 & 779 & 4.00 \\
10.00 & 7.00 & 5.125 & 1523.4 & 3.70 \\
10.00 & 8.00 & 1.134 & 2771 & 8.70 \\
10.00 & 9.00 & 0.216 & 3058 & 9.30 \\
10.00 & 10.00 & 0.015 & 3120 & 9.60 \\
10.00 & 11.00 & 0.007 & 3123 & 11.00 \\
10.00 & 12.00 & 0.003 & 3124 & 11.50 \\
\hline
\end{tabular}

C: Concentration of $\mathrm{Co}$ in equilibrium solution

q:Adsorbed Co

Nano particles Zero-Valeant iron (nZVI):

Selenate

The adsorption envelopes for selenate at the initial solution concentration equivalent to $10 \mu \mathrm{g} \mathrm{Se} \mathrm{mL}^{-1}$ indicated adsorption of nearly $100 \%$ of total selenate added throughout the $\mathrm{pH}$ value of 3-4 (Table, 3). With increasing $\mathrm{pH}$ value more than 4 , selenate adsorption declined sharply to reach at $\mathrm{pH} 12$ be $16 \%$ of the maximum adsorption of Se. Similar results were reported by Abd El- Haleem (2001) in which adsorption envelopes of $\mathrm{AsO}_{4}{ }^{3-}$ reveal that the highest $\mathrm{AsO}_{4}{ }^{3-}$ adsorption occurred at low $\mathrm{pH}(<4.0)$. 
Sherif, A. E. A. et al.

The adsorption envelopes exhibited broad adsorption maxima for selenate in the $\mathrm{pH}$ range of 3-4 which was followed by a gradual decline with increasing $\mathrm{pH}$ to more the 4. Inflections or maxima in the adsorption envelopes of anions at $\mathrm{pH}$ values close to their $\mathrm{pKa}$ are well documented phenomenon (Stumm, 1992 and Abd El- Haleem 2001).

Selenate adsorption decreased almost linearly from almost $24960 \mu \mathrm{g}$ Se $\mathrm{g}^{-1} \mathrm{nZVI}$, at pH 3 to $4160 \mu \mathrm{g} \mathrm{Se} \mathrm{g}^{-1} \mathrm{nZVI}$ at pH 11. The lower adsorption of selenate at high $\mathrm{pH}$ values is attributable to an increased repulsion between the more negatively selenate species and negatively charged surface sites (Raven et al., 1998). These results are confirmed with those of Griffin and Shimp (1978) in which maximum adsorption of selenate by kaolinite and montmorillonite, occurred at $\mathrm{pH} \mathrm{5}$. Adsorption of selenate by aluminum and iron oxides has shown an adsorption maximum at $\mathrm{pH}$ 3-4 followed by a gradual decrease in adsorption with increasing pH (Hingston et al., 1971; Anderson et al., 1976)

Cobalt

In case of Co adsorption by nZVI, results in Table (4) indicate that adsorption of Co showed an opposite trend to arsenate as its quantities increased with increasing $\mathrm{pH}$. The highest Co adsorption was noticed at $\mathrm{pH}$ 8.0 with a constant adsorption values with $\mathrm{pH}>7.0$. The highest Co adsorption was $24973 \mu \mathrm{g} \mathrm{Co} \mathrm{g}{ }^{-1} \mathrm{nZVI}$ which corresponded to $99 \%$ of total added Co. The adsorption process may be responsible for decreasing Co concentration in equilibrium solution, particularly at $\mathrm{pH}<7.0$. However, at $\mathrm{pH}$ values $>7.0$ both adsorption and precipitation may be responsible for decreasing Co concentration in equilibrium solution and account for the retention of Co by nZVI.

Table (3): Selenate adsorption on nano particles zero-valeant iron (nZVI) as a function of $\mathrm{pH}\left(\mathrm{Se} 10 \mu \mathrm{g} \mathrm{mL}^{-1}\right.$, ionic strength, $0.1 \mathrm{M}$ $\mathrm{NaCl})$

\begin{tabular}{|c|c|c|c|c|}
\hline $\begin{array}{l}\text { Initial conc. of } \\
\text { Se } \mu \mathrm{g} \mathrm{mL}\end{array}$ & $\begin{array}{c}\mathrm{pH} \\
\text { initial }\end{array}$ & $\begin{array}{c}\mathrm{C} \\
\mu \mathrm{g} \mathrm{mL^{-1 }}\end{array}$ & $\mu^{q} g^{-1}$ & $\begin{array}{c}\mathrm{pH} \\
\text { Final }\end{array}$ \\
\hline 10.00 & 3.00 & 0.016 & 24960 & 3.50 \\
\hline 10.00 & 4.00 & 0.058 & 24855 & 3.90 \\
\hline 10.00 & 5.00 & 0.073 & 24818 & 3.90 \\
\hline 10.00 & 6.00 & 0.103 & 24743 & 4.00 \\
\hline 10.00 & 7.00 & 0.197 & 24508 & 3.70 \\
\hline 10.00 & 8.00 & 0.586 & 22860 & 8.70 \\
\hline 10.00 & 9.00 & 1.83 & 20415 & 9.30 \\
\hline 10.00 & 10.00 & 6.38 & 9058 & 9.60 \\
\hline 10.00 & 11.00 & 8.34 & 4160 & 11.00 \\
\hline 10.00 & 12.00 & 9.65 & 875 & 11.50 \\
\hline
\end{tabular}


Table (4): Cobalt adsorption on nano particles zero-valeant iron (nZVI) as a function of $\mathrm{pH}$ ( Co $10 \mu \mathrm{g} \mathrm{mL}^{-1}$, ionic strength, $0.1 \mathrm{M}$ $\mathrm{NaCl})$

\begin{tabular}{|c|c|c|c|c|}
\hline $\begin{array}{l}\text { Initial conc. of } \\
\text { Co } \mu \mathrm{g} \mathrm{mL}\end{array}$ & $\begin{array}{c}\mathrm{pH} \\
\text { initial }\end{array}$ & $\begin{array}{c}\mathrm{C} \\
\mu \mathrm{g} \mathrm{mL}^{-1}\end{array}$ & $\begin{array}{c}Q \\
\mu g g^{-1}\end{array}$ & $\begin{array}{c}\mathrm{pH} \\
\text { Final }\end{array}$ \\
\hline 10.00 & 3.00 & 9.90 & 253 & 3.70 \\
\hline 10.00 & 4.00 & 9.72 & 705 & 3.80 \\
\hline 10.00 & 5.00 & 8.57 & 3575 & 3.50 \\
\hline 10.00 & 6.00 & 7.01 & 7473 & 3.80 \\
\hline 10.00 & 7.00 & 4.66 & 13345 & 4.00 \\
\hline 10.00 & 8.00 & 1.90 & 20240 & 3.20 \\
\hline 10.00 & 9.00 & 0.243 & 24393 & 4.20 \\
\hline 10.00 & 10.00 & 0.011 & 24973 & 8.70 \\
\hline 10.00 & 11.00 & 0.001 & 24998 & 9.12 \\
\hline 10.00 & 12.00 & 0.001 & 24998 & 11.0 \\
\hline
\end{tabular}

\section{CONCLUSIONS}

Goethite and nano particles zero-valent iron were used as adsorbents for both $\mathrm{Se}$ and $\mathrm{Co}$. The results proved that the sorption capacities of Goethite and nano particles zero-valent iron were $\mathrm{pH}$ dependent. These materials can be used for removing contaminants from waste water plants before dumping it into the canals and the work of this material filters.

The $\mathrm{pH}$ is an important factor affecting the sorption of selenium and Co by Goethite and nano particles zero-Valeant iron, and it can change the affinity of the sorption sites for heavy metals. Selenium and Cobalt adsorption can be achieved using an initial solution $\mathrm{pH}$. There for adsorption capacity of materials using was different with change of $\mathrm{pH}$ selenium is more adsorped in acid medium while cobalt is more adsorbed in alkaline side.With a careful selection of the other conditions, especially the metal ion and slurry concentrations, to avoid masking of sorption by chemical precipitation.

\section{REFERENCES}

Abd El-Haleem, A.A (2001). Kinetics and pH envelopes arsenite and arsenate adsorption on goethite. Annals of Agric. Sc, Moshtohor, 39:2399-2420.

Al-Sewailem, M.S, E.M. K. Khaled and A.S. Mashhady ( 2000) Effect of synthetic ferric hydroxides on retention of zinc by sand and its extractability. Egyptian J. Soil Sci. 40: 329-341.

Anderson, M.C., J.F.Ferguson and J.Gavis. ( 1976) Arsenate adsorption on amorphous aluminum hydroxide. J. Colloid Interface Sci. 54:391-399.

Bisbjerg B. (1972) Riso report no. 200: Studies on selenium in plants and soils. Copenhagen, Denmark : Danish Atomic Energy Comission Research Establishment Riso. 
Chapman, P.M. (2000) Selenium - fate and effects in the aquatic environment. Presented at the 24th Annual British Columbia Mine Reclamation Symposium, Williams Lake, BC.

Gomez-Lahoz C, F.Garcia-Herruzo, J.M.Rodriguez-Maroto, and J.J.Rodriguez (1993) Cobalt(II) removal from water by chemicalreduction with borohydride. Water Res;27:985-92.

Griffin R.A. and N.F. Shimp. (1978)Attenuation of pollutants in municipal landfill leachate by clay minerals. EPA-600/2-78-157.

Haygarth, P.M. (1994) "Global importance and global cycling of selenium." In Selenium in the Environment, W.T. Frankenberger and S. Benson (eds). Marcel Dekker, NY: 1-28

Hingston F.J., A.M.Posner and J.P.Quick (1971) Competitive adsorption of negatively charged ligands on oxide surfaces. Faraday Soc. 52 :334342.

Lenz, M. (2008) Biological selenium removal from wastewaters. Ph.D. Thesis, WageningenUniversity, Wageningen, The Netherlands.

Lovett, R. ( 2008) Selenium removal from mine waters. Presented at the Annual Meeting of the West Virginia Surface Mine Drainage Task Force, Morgantown, WV on 23 April.

Manning B.A., S.E.Fendorf. and S. Goldberg (1998) Surface structures and stability of arsenic(III) on goethite: Spectroscopic evidence for innersphere complexes. Environ. Sci. and Technol. 32:383-2388.

Microbial Technologies. (2005)Literature review: Evaluation of treatment options to reduce waterborne selenium at coal mines in West-Central Alberta. Report prepared by MicrobialTechnologies, Inc. for Alberta Environment, Water Research Users Group, Edmonton, AB.

Naidu, R., N.S.Bolan, R.S.Kookana, and R.G.Tiller (1994) lonic-strength and $\mathrm{pH}$ effects on the sorption of cadmium and the surface charge of soils. European Journal of Soil Science, 45:419-429.

Netzer A., and D.E.Hughes (1984) Adsorption of copper, lead and cobalt by activated carbon. Water Res;18:927-33.

Periasamy K, K.Srinivasan and P.K.Murugan (1991) Studies on chromium(VI) removal by activated groundnut husk carbon. Indian $\mathrm{J}$ Environ Health; 33:433-9.

Poon C.P.C. (1986) Removal of cadmium from wastewaters. In: Mislin H, Ravera $\mathrm{O}$, editors. Cadmium in the environment. Basel, Switzerland: Birkhauser,. p. 46-55.

Raven. K., A. Jain and R. H. Loeppert. (1998) Arsenite and arsenate adsorption on ferrihydrite, kinetics, equilibrium, and adsorption envelopes. Environ. Sci Technol. 32:344-349.

Renella, g., P.Adamo, M.R. Bianco, L.Landi, P.Violante and P.Nannipieri (2004).Availability and speciation of cadmium added to a calcareous soil under various managements. European Journal of Soil Science, 55:123-133.

Schwertmann, U. and R.M. Cormell (1991) Iron oxides in the Laboratory. Wiley-VCH, Weinheim. 
